University of Nebraska - Lincoln

DigitalCommons@University of Nebraska - Lincoln

1969

\title{
Effects of Dietary Levels of Manganese and Magnesium on Performance of Growing-Finishing Swine Raised in Confinement and on Pasture
}

\author{
A. J. Svajgr \\ University of Kentucky \\ E. R. Peo, Jr. \\ University of Nebraska-Lincoln \\ P. E. Vipperman, Jr. \\ University of Nebraska-Lincoln
}

Follow this and additional works at: https://digitalcommons.unl.edu/animalscifacpub

Part of the Animal Sciences Commons

Svajgr, A. J.; Peo, Jr., E. R.; and Vipperman, Jr., P. E., "Effects of Dietary Levels of Manganese and Magnesium on Performance of Growing-Finishing Swine Raised in Confinement and on Pasture" (1969). Faculty Papers and Publications in Animal Science. 630.

https://digitalcommons.unl.edu/animalscifacpub/630

This Article is brought to you for free and open access by the Animal Science Department at DigitalCommons@University of Nebraska - Lincoln. It has been accepted for inclusion in Faculty Papers and Publications in Animal Science by an authorized administrator of DigitalCommons@University of Nebraska - Lincoln. 


\title{
EFFECTS OF DIETARY LEVELS OF MANGANESE AND MAGNESIUM ON PERFORMANCE OF GROWING- FINISHING SWINE RAISED IN CONFINEMENT AND ON PASTURE ${ }^{1}$
}

\author{
A. J. Svajgr, ${ }^{2}$ E. R. Peo, Jr. and P. E. Vipperman, JR. \\ Nebraska Agricultural Experiment Station, Lincoln ${ }^{3}$
}

$\mathbf{R}^{\mathrm{H}}$ ESEARCH on the optimum dietary levels of manganese and magnesium for growing swine is limited. Johnson (1940) fed pigs diets containing 0.3 to $100 \mathrm{ppm} \mathrm{Mn}$ and observed no difference in growth rate. Similarly, Liebholz, Speer and Hays (1962) found that 0.4 ppm $\mathrm{Mn}$ in the diet of baby pigs was sufficient to support maximum growth. A level of 4,000 ppm Mn was not toxic but growth rate of the pigs was reduced.

No difference in growth rate and feed effciency was found in pigs fed semi-purified diets from weaning to market weight when levels of $\mathrm{Mn}$ ranged from 0.5 to $40 \mathrm{ppm}$ (Plumlee et al., 1956). Grummer et al. (1950) fed pigs a basal diet containing $12 \mathrm{ppm}$ Mn supplemented with 40, 80 and $160 \mathrm{ppm} \mathrm{Mn}$. Pigs consuming diets supplemented with $40 \mathrm{ppm}$ gained significantly faster than those on the basal diet but performance was not improved with higher levels of Mn.

Miller et al. (1963, 1965, 1965a,), studying the magnesium requirement of the baby pig, found that $325 \mathrm{ppm}$ was adequate for normal growth; whereas Mayo, Plumlee and Beeson (1959) reported that 400 to $500 \mathrm{ppm} \mathrm{Mg}$ was needed in the diet for maximum gains in pigs from weaning ( 3 or 9 weeks of age) to market weight.

Little research has been reported on possible interrelationships among $\mathrm{Mn}, \mathrm{Mg}$ and environment in swine. Therefore, the research reported here was conducted to determine the effect of various levels of supplemental $\mathrm{Mn}$ and $\mathbf{M g}$, singly and in combination, on gain, feed conversion and certain bone characteristics of growing swine, raised in confinement and on pasture.

1 Published with the approval of the Director as Paper No. 2618, Journal Series, Nebr. Agr. Exp. Sta.

2 Current address: Cooperative Extension Service, University of Kentucky, Louisville.

3 Department of Animal Science. Acknowledgement is made to Mr. Guy Fields for assistance in preparation of the diets and to Dawes Laboratories, Inc., Chicago, Ill., for providing the vitamin premix used.

\section{Materials and Methods}

One hundred and ninety-eight crossbred pigs averaging $17.3 \mathrm{~kg}$. were allotted at random within weight groups to three replications in a $2 \times 2 \times 3$ factorial arrangement of six dietary treatments on either pasture or confinement to concrete. Barrows and gilts were balanced within treatments with 15 pigs per treatment in confinement on concrete and 18 pigs per treatment on alfalfa-brome pasture. Composition of the experimental diets is shown in table 1.

Manganese and magnesium were supplemented to the diet at $0 / 0,50 / 0,100 / 0,0 / 100$, $50 / 100$ and $100 / 100 \mathrm{ppm}$ for treatments 1 through 6 , respectively. A $14 \%$ protein diet was fed throughout the experiment with both calcium and phosphorus maintained at $0.65 \%$. All pigs were provided water from the City of Lincoln water system. The pigs were slaughtered at approximately $98 \mathrm{~kg}$. of body weight.

Just prior to slaughter, blood was drawn from the brachial veins and allowed to coagulate. After centrifugation the serum portion was removed for analysis of $\mathrm{Mn}$ and $\mathrm{Mg}$. $\mathrm{Mg}$ concentration was determined with a PerkinEImer Model 303 atomic absorption spectrophotometer $^{4}$ using a 25:1 dilution with distilled water. Manganese levels in the serum were apparently too low for detection with the spectrophotometer. No attempt was made to concentrate the serum.

The hind legs were obtained from the carcasses at the George A. Hormel Packing Plant, Fremont, Nebraska. The fourth metatarsal bone of the right hind leg was excised, identified by number with India ink, and boiled in water for 10 minutes. Following boiling, all fleshy tissue was scraped from the bone and it was allowed to air-dry for 5 days. The metatarsals were then prepared for fat extraction

\footnotetext{
4 Perkin-Elmer Corporation, Norwalk, Connecticut.
} 
TABLE 1. COMPOSITION OF EXPERIMENTAL DIETS ${ }^{a, b}$

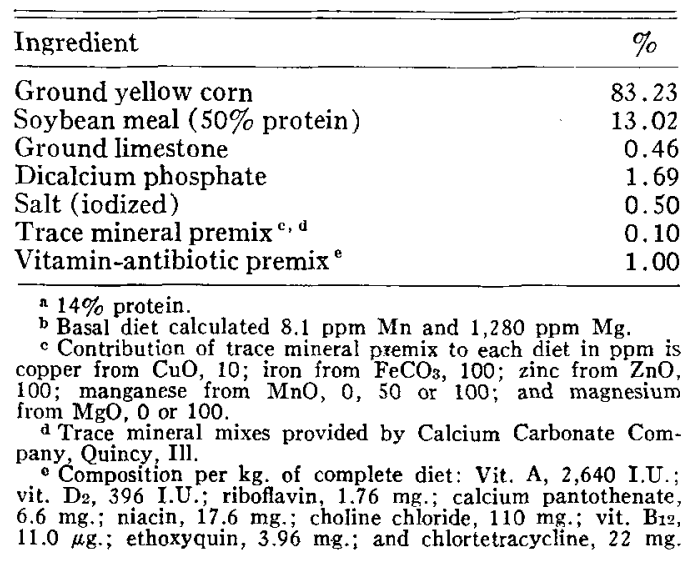

by drilling a $0.30 \mathrm{~cm}$. hole in each end at the epyphisial cartilage and placed in methyl alcohol for 48 hours. The metatarsals were airdried for $48 \mathrm{hr}$., oven dried at $100^{\circ} \mathrm{C}$. for 12 hr. and then extracted with anhydrous ethyl ether in a side chamber apparatus for $12 \mathrm{hr}$. and allowed to air-dry for 10 days.

The breaking strength (BKS) of the metatarsals was determined by using a Fred $S$. Carver Laboratory Press. ${ }^{5}$ The pressure re-

\footnotetext{
Fred S. Carver, Inc., One Chatham Road, Summit, New Jersey.
}

quired to supply the force to break the bones was read directly from a gauge and is the value reported.

The broken metatarsals were dried for 24 hr. at $100^{\circ} \mathrm{C}$. prior to weighing for ashing. The bones were ashed at $700^{\circ} \mathrm{C}$. (Blair, Diack and Macpherson, 1963) in a muffle furnace for 10 hours. The ash was ground and a sample treated with ml. of $4 \mathrm{~N} \mathrm{HCl}$ and heated in a water bath at $60^{\circ} \mathrm{C}$. to complete the dissolution of the ash. The samples were analyzed for $\mathrm{Mn}$ and $\mathrm{Mg}$ by atomic absorption spectrophotometry.

The ash sample was diluted 1,000:1 with $0.10 \%$ lanthanum solution for Mn analysis and 5,000:1 with distilled water for $\mathrm{Mg}$ determinations.

The data were analyzed statistically by analysis of variance methods (Steel and Torrie, 1960).

\section{Results and Discussion}

Treatment means for criteria of response are presented in tables 2 and 3 . Gains were depressed when $50 \mathrm{ppm}$ Mn was supplemented, which resulted in a significant quadratic effect $(\mathrm{P}<.05)$ of $\mathrm{Mn}$ levels on average daily gain. This observation does not agree with Grummer et al. (1950) who observed maximum gains when pigs were fed $52 \mathrm{ppm} \mathrm{Mn}$ or Plumlee $e t$

TABLE 2, EFFECT OF ADDED DIETARY LEVELS OF MN AND MG CN GAIN, FEED INTAKE AND FEED/GAIN OF SWINE ${ }^{a, b}$

\begin{tabular}{|c|c|c|c|c|c|c|c|}
\hline \multicolumn{4}{|c|}{ Confinement ${ }^{c}$} & \multicolumn{4}{|c|}{ Pasture } \\
\hline \multirow[b]{2}{*}{ Mn, ppm } & \multicolumn{3}{|c|}{ Mg, ppm } & \multirow[b]{2}{*}{ Mn, ppm } & \multicolumn{3}{|c|}{$\mathrm{Mg}, \mathrm{ppm}$} \\
\hline & 0 & 100 & Av. Mn & & 0 & 100 & Av. $\mathrm{Mn}$ \\
\hline \multicolumn{8}{|c|}{ Av. daily gain, kg. } \\
\hline 0 & 0.83 & 0.80 & 0.81 & 0 & 0.83 & 0.81 & 0.82 \\
\hline 50 & 0.76 & 0.82 & 0.79 & 50 & 0.85 & 0.77 & 0.81 \\
\hline 100 & 0.83 & 0.84 & 0.84 & 100 & 0.84 & 0.81 & 0.83 \\
\hline Av. $\mathrm{Mg}$ & 0.80 & 0.82 & $\ldots$ & Av. Mg & 0.84 & 0.80 & $\ldots$ \\
\hline \multicolumn{8}{|c|}{ Av. daily feed intake, $\mathrm{kg} .{ }^{\mathrm{s}}$} \\
\hline 0 & 2.43 & 2.40 & 2.41 & 0 & 2.35 & 2.22 & 2.29 \\
\hline 50 & 2.24 & 2.37 & $=30$ & 50 & 2.38 & 2.18 & 2.29 \\
\hline 100 & 2.42 & 2.41 & 2.41 & 100 & 2.39 & 2.26 & 2.33 \\
\hline Av. $\mathbf{M g}$ & 2.36 & 2.39 & $\ldots$ & Av. Mg & 2.37 & 2.22 & $\ldots$ \\
\hline \multicolumn{8}{|c|}{ Av. feed/gain } \\
\hline 0 & 2.93 & 2.96 & 2.94 & 0 & 2.84 & 2.73 & 2.78 \\
\hline 50 & 2.91 & 2.86 & 2.89 & 50 & 2.79 & 2.82 & 2.80 \\
\hline 100 & 2.88 & 2.84 & 2.86 & 100 & 2.83 & 2.75 & 2.79 \\
\hline Av. $\mathbf{M g}$ & 2.91 & 2.89 & $\ldots$ & Av. $\mathbf{M g}$ & 2.82 & 2.76 & $\ldots$ \\
\hline
\end{tabular}

a Basal $14 \%$ protein corn-soybean meal diet.

b Av initial wt. $17.4 \mathrm{~kg}$., duration of test, 84 days.

c 15 pigs/treatment

¿ 18 pigs/treatment

- Quadratic effect of $\mathrm{Mn}$ !evels significant $(P<.05)$.

1 Location $\times \mathrm{Mg}$ interaction significant $(\mathrm{P}<.10)$

Location $x \mathrm{Mg}$ interaction significant $(\mathrm{P}<.05)$ 
TABLE 3. EFFECT OF ADDED DIETARY LEVELS OF MN AND MG ON METATARSAL BREAKING STRENGTH, PERCENT BONE ASH, BONE MN AND MG AND BLOOD MG OF SWINE

\begin{tabular}{|c|c|c|c|c|c|c|c|}
\hline \multicolumn{4}{|c|}{ Confinement } & \multicolumn{4}{|c|}{ Pasture } \\
\hline \multirow[b]{2}{*}{ Mn, ppm } & \multicolumn{3}{|c|}{$\mathrm{Mg}, \mathrm{ppm}$} & \multirow[b]{2}{*}{$\mathrm{Mn}, \mathrm{ppm}$} & \multicolumn{3}{|c|}{$\mathrm{Mg}, \mathrm{ppm}$} \\
\hline & 0 & 100 & Av. Mn & & 0 & 100 & Av. Mn \\
\hline \multicolumn{8}{|c|}{ Metatarsal breaking strength, $\mathrm{kg} . / \mathrm{cm}^{2 a, b, c, a}$} \\
\hline $\begin{array}{c}0 \\
50 \\
100 \\
\text { Av. Mg }\end{array}$ & $\begin{array}{l}9.6 \\
6.7 \\
7.6 \\
8.0\end{array}$ & $\begin{array}{l}7.6 \\
7.2 \\
8.2 \\
7.6\end{array}$ & $\begin{array}{l}8.6 \\
7.0 \\
7.9 \\
\ldots\end{array}$ & $\begin{array}{c}0 \\
50 \\
100 \\
\text { Av. Mg }\end{array}$ & $\begin{array}{l}15.2 \\
12.9 \\
17.6 \\
15.2\end{array}$ & $\begin{array}{l}12.8 \\
13.5 \\
18.7 \\
15.0\end{array}$ & $\begin{array}{l}14.0 \\
13.2 \\
18.2 \\
\ldots .\end{array}$ \\
\hline \multicolumn{8}{|c|}{ Bone Ash, \% of dry fat-free bone e, } \\
\hline $\begin{array}{c}0 \\
50 \\
100 \\
\text { Av. } \mathrm{Mg}\end{array}$ & $\begin{array}{l}55.3 \\
54.8 \\
54.8 \\
55.0\end{array}$ & $\begin{array}{l}54.3 \\
53.6 \\
55.4 \\
54.4\end{array}$ & $\begin{array}{l}54.8 \\
54.2 \\
55.1 \\
\ldots .\end{array}$ & $\begin{array}{c}0 \\
50 \\
100 \\
\text { Av. } \mathrm{Mg}\end{array}$ & $\begin{array}{l}56.4 \\
57.0 \\
58.0 \\
57.1\end{array}$ & $\begin{array}{l}55.1 \\
56.8 \\
56.1 \\
56.0\end{array}$ & $\begin{array}{l}55.7 \\
56.9 \\
57.1 \\
\ldots \ldots\end{array}$ \\
\hline \multicolumn{8}{|c|}{ Bone $\mathrm{Mn}, \mathrm{ppm}$ of bone ash } \\
\hline $\begin{array}{c}0 \\
50 \\
100 \\
\text { Av. } \mathrm{Mg}\end{array}$ & $\begin{array}{l}7.5 \\
7.2 \\
7.7 \\
7.4\end{array}$ & $\begin{array}{l}7.2 \\
7.6 \\
7.4 \\
7.4\end{array}$ & $\begin{array}{l}7.3 \\
7.4 \\
7.5 \\
\ldots\end{array}$ & $\begin{array}{c}0 \\
50 \\
100 \\
\text { Av. } \mathrm{Mg}\end{array}$ & $\begin{array}{l}7.0 \\
7.4 \\
7.4 \\
7.2\end{array}$ & $\begin{array}{l}7.2 \\
7.4 \\
7.2 \\
7.3\end{array}$ & $\begin{array}{l}7.1 \\
7.4 \\
7.3 \\
\ldots\end{array}$ \\
\hline \multicolumn{8}{|c|}{ Bone $\mathrm{Mg}, \%$ of bone ash ${ }^{\mathrm{g}}$} \\
\hline $\begin{array}{c}0 \\
50 \\
100 \\
\text { Av. } \mathrm{Mg}\end{array}$ & $\begin{array}{l}0.89 \\
0.89 \\
0.90 \\
0.89\end{array}$ & $\begin{array}{l}0.98 \\
0.94 \\
0.98 \\
0.97\end{array}$ & $\begin{array}{l}0.94 \\
0.92 \\
0.94 \\
\ldots .\end{array}$ & $\begin{array}{c}0 \\
50 \\
100 \\
\text { Av. } \mathrm{Mg}\end{array}$ & $\begin{array}{l}1.03 \\
0.94 \\
0.98 \\
0.98\end{array}$ & $\begin{array}{l}0.93 \\
0.95 \\
0.91 \\
0.93\end{array}$ & $\begin{array}{l}0.98 \\
0.94 \\
0.94 \\
\ldots \ldots\end{array}$ \\
\hline \multicolumn{8}{|c|}{ Blood Mg, ppm ${ }^{\mathrm{h}, \mathrm{t}, \mathrm{j}}$} \\
\hline $\begin{array}{r}0 \\
50 \\
100 \\
\text { Av. Mg } \\
\end{array}$ & $\begin{array}{l}2.6 \\
2.9 \\
2.7 \\
2.7\end{array}$ & $\begin{array}{l}2.4 \\
2.7 \\
2.5 \\
2.5 \\
\end{array}$ & $\begin{array}{l}2.5 \\
2.8 \\
2.6 \\
\ldots\end{array}$ & $\begin{array}{c}0 \\
50 \\
100 \\
\text { Av. } \mathrm{Mg}\end{array}$ & $\begin{array}{l}3.4 \\
2.6 \\
3.4 \\
3.1 \\
\end{array}$ & $\begin{array}{l}2.8 \\
3.0 \\
3.0 \\
2.9 \\
\end{array}$ & $\begin{array}{l}3.1 \\
2.8 \\
3.2 \\
\ldots\end{array}$ \\
\hline $\begin{array}{l}\text { a Presse } \\
\text { b Locat } \\
\text { c Quadr } \\
\text { a Locati } \\
\text { o Locat } \\
\text { f Level } \\
\text { g Locati } \\
\text { h Locati } \\
\text { 1 Level } \\
\text { I Locati }\end{array}$ & $\begin{array}{l}\text { uired to } \\
\text { ct signif } \\
\text { d linear } \\
\text { In inter: } \\
\text { ct signif } \\
\text { significa } \\
\text { Ig inter: } \\
\text { ct signif } \\
\text { significa } \\
\text { An intera }\end{array}$ & $\begin{array}{l}\text { force to } \\
\text { P<.005) } \\
\text { o Mn lev } \\
\text { ignificant } \\
\text { P<.10). } \\
\text { igs). } \\
\text { ignificant } \\
\text { (2<.01). } \\
(10) \text {. } \\
\text { ignificant }\end{array}$ & $\begin{array}{l}\text { etatarsal be } \\
\text { ificant }(\mathrm{P}< \\
0) \\
\text { 25). }\end{array}$ & (10) & & & \\
\hline
\end{tabular}

al. (1956) who found no difference in gain and feed efficiency of growing pigs fed 0.5 to 40 ppm Mn.

Average daily gain was also reduced $(\mathrm{P}<$ $.10)$ in pigs on pasture compared to those in confinement when $100 \mathrm{ppm} \mathrm{Mg}$ was added to the diet $(0.80$ vs. $0.84 \mathrm{~kg}$.). A location $\mathrm{x} \mathrm{Mg}$ interaction effect $(P<.10)$ was also observed for gain. With $100 \mathrm{ppm} \mathrm{Mg}$, gains were increased in confinement but were lower with the higher level of $\mathrm{Mg}$ on pasture. This effect may be accounted for by a significant $(\mathrm{P}<.05)$ location $\times \mathrm{Mg}$ interaction upon feed intake. Pigs fed $100 \mathrm{ppm} \mathrm{Mg}$ on pasture had a lower daily feed intake $(\mathrm{P}<.05)$ than those in confinement (2.22 vs. $2.37 \mathrm{~kg}$.). Feed/gain ratio was not significantly affected by any of the treatments.
Percent bone ash was greater $(\mathrm{P}<.10)$ for pigs grown on pasture than for those raised in confinement $(56.6 \%$ vs. $54.7 \%)$. When averaged across both locations, percent bone ash was significantly lower $(P<.05)$ when 100 $\mathrm{ppm} \mathrm{Mg}$ was supplemented.

Dietary levels of 0, 50 and $100 \mathrm{ppm}$ supplemental Mn resulted in BKS of the fourth metatarsal bones of $11.4,10.1$ and $13.0 \mathrm{~kg} . / \mathrm{cm} .{ }^{2}$, respectively. The quadratic effect of Mn levels on BKS was significant $(\mathrm{P}<.025)$. Also a location $\mathrm{x} \mathrm{Mn}$ interaction $(\mathrm{P}<.05)$ was observed for BKS. When $100 \mathrm{ppm}$ Mn was added to the diet in confinement, BKS decreased. The reverse was true for pigs raised on pasture.

The BKS of metatarsals from pigs raised on pasture was almost twice as great as from pigs raised in confinement, 7.82 vs. $15.20 \mathrm{~kg}$./ 
$\mathrm{cm}^{2}$, respectively. The difference was highly significant $(\mathrm{P}<.005)$. The great difference in BKS of pigs reared in the two environments is unexplained at this time since no measure of forage intake was made for the pigs on pasture.

Bone $\mathrm{Mn}$ and $\mathrm{Mg}$ levels were not changed by level in the diet. There was a location $\mathrm{x} \mathrm{Mg}$ interaction $(\mathrm{P}<.10)$ on bone $\mathrm{Mg}$. Bones from pigs raised in confinement and supplemented with 0 and $100 \mathrm{ppm} \mathrm{Mg}$ analyzed 0.89 and $0.97 \% \mathrm{Mg}$; whereas bones from pigs grown on pasture contained 0.98 and $0.92 \% \mathrm{Mg}$ for the respective dietary levels of $\mathrm{Mg}$. The pigs raised in confinement had bone $\mathrm{Mg}$ levels which were positively related to dietary $\mathrm{Mg}$ intake. The opposite effect on pasture may reflect the unknown intake of all minerals from the forage and soil.

Blood Mg levels were significantly lower $(\mathrm{P}<.025)$ in pigs grown in confinement compared to those on pasture. This again may reflect a possible intake of $\mathrm{Mg}$ from the forage or soil.

A location $\mathrm{x} \mathrm{Mn}$ interaction $(\mathrm{P}<.025)$ on blood $\mathrm{Mg}$ level existed between pigs raised in confinement and those on pasture at the three levels of supplemental Mn. Supplementing 50 ppm Mn to diets of pigs in confinement resulted in the highest blood $\mathrm{Mg}$ levels but the lowest on pasture.

Dietary Mg tended to have a negative effect $(\mathrm{P}<.10)$ on blood $\mathrm{Mg}$ levels. Pigs in confinement and on pasture had higher serum $\mathrm{Mg}$ levels when no $\mathrm{Mg}$ was supplemented. The blood $\mathrm{Mg}$ levels when 0 and $100 \mathrm{ppm} \mathrm{Mg}$ were supplemented were 2.9 and $2.8 \mathrm{ppm}$, respectively. The effect of supplemental Mg on blood $\mathrm{Mg}$ levels was the opposite of that which was expected. However, Tillman (1966) suggested that excess $\mathrm{Mg}$ antagonizes calcium and phosphorus, allowing for a lower absorption and greater excretion of both $\mathrm{Mg}$ and calcium.

\section{Summary}

Manganese and magnesium were supplemented to a corn-soybean meal base diet fed to pigs in confinement and on pasture at the following rates in ppm: $0 / 0,50 / 0,100 / 0$, $0 / 100,50 / 100$ and $100 / 100$.

Average daily gain was significantly reduced when $50 \mathrm{ppm} \mathrm{Mn}$ was supplemented to the diet. Supplementing $\mathrm{Mg}$ at $100 \mathrm{ppm}$ to pigs on pasture also reduced gains compared to pigs in confinement. A location $\mathrm{x} \mathrm{Mg}$ interaction for gain and feed intake was observed.
Pigs in confinement grew faster and ate more feed when $100 \mathrm{ppm} \mathrm{Mg}$ was added to the diet in confinement but both were reduced when this level was fed on pasture. Feed/gain was not significantly affected by any of the treatments.

Percent bone ash was significantly increased when pigs were grown on pasture and when $100 \mathrm{ppm} \mathrm{Mg}$ was added to the diet when averaged across both locations.

Breaking strength of the fourth metatarsal bone of pigs grown on pasture was almost twice that of pigs raised in confinement with the difference being highly significant. The quadratic component of the effect of levels of $\mathrm{Mn}$ on breaking strength was significant with diets containing $50 \mathrm{ppm}$ producing bones with the lowest strength. 'The location $\mathrm{x} \mathrm{Mg}$ interaction was significant. Thus, adding $100 \mathrm{ppm} \mathrm{Mn}$ in confinement reduced bone strength but increased it when this level was supplemented on pasture.

Supplementing $\mathrm{Mg}$ in confinement increased bone $\mathrm{Mg}$ levels, but the reverse occurred for pigs on pasture. Supplementing $100 \mathrm{ppm} \mathrm{Mg}$ reduced serum $\mathrm{Mg}$ levels in both environments. Pigs raised in confinement also had significantly lower serum $\mathrm{Mg}$ levels than pigs reared on pasture. A location $\mathrm{x} M \mathrm{M}$ interaction was observed for serum $\mathrm{Mg}$ with $50 \mathrm{ppm} \mathrm{Mn}$ in confinement producing the highest serum $\mathrm{Mg}$ levels and the lowest on pasture.

The pronounced difference in breaking strength of the metatarsals of pigs raised in confinement and on pasture is unexplained at this time.

\section{Literature Cited}

Blair, R., J. R. B. Diack and R. M. Macpherson. 1963. Bone development in suckling pigs. British J. Nutr, 17:19.

Grummer, R. H., O. G. Bentley, P. H. Phillips and G. Bohstedt. 1950. The role of manganese in growth, reproduction and lactation of swine. J. Animal Sci. 9:170.

Johnson, S. R. 1940. Growth on manganese low rations. Am. Soc. of An. Prod. 40:325.

Leibholz, J. M., V. C. Speer and V. W. Hays. 1962. Effect of dietary manganese on baby pig performance and tissue manganese levels. J. Animal Sci. $21: 772$.

Mayo, R. H., M. P. Plumlee and W. M. Beeson. 1959. Magnesium requirement of the pig. J. Animal Sci. $18: 264$.

Miller, E. R., D. E. Ullrey, C. L. Zutaut, J. A. Hoefer and R. W. Luecke. 1963. Effects of dietary vitamin $\mathrm{D}_{2}$ and magnesium upon calcium, phosphorus and magnesium utilization by the baby pig. Fed. Proc. 22:491. (Abstr.).

Miller, E. R., D. E. Ullrey, C. L. Zutaut, B. V. 
Baltzer, D. A. Schmidt, J. A. Hoefer and R. W. Luecke. 1965. Magnesium requirement of the baby pig. J. Nutr. 85:13.

Miller, E. R., D. E. Ullrey, C. L. Zutaut, J. A. Hoefer and R. W. Luecke. 1965a. Mineral balance studies with baby pigs: Effects of dietary magnesium level upon calcium, phosphorus, and magnesium balance. J. Nutr. 86:209.

Plumlee, M. P., D. M. Thrasher, W. M. Beeson, F.
N. Andrews and H. E. Parker. 1956. The effects of a manganese deficiency upon the growth, development and reproduction of swine. J. Animal Sci. $15: 352$.

Steel, R. G. D. and J. H. Torrie. 1960. Principles and Procedures of Statistics. McGraw-Hill Book Co., New York.

Tillman, A. D. 1966. Recent developments in beef cattle feeding. Proc. Pfizer Res. Conf. 14:15. 